\title{
Access to and use of Information on Credit Facilities by Farmers in Kiambu County
}

\author{
Wambui Phyllis Wagacha*, Cephas Odini \\ Moi University, School of Information Sciences, P.O. Box 3900- 30100, Eldoret, Kenya
}

DOI: $10.36348 /$ sjhss.2020.v05i07.003 $\quad$ | Received: 03.06.2020 | Accepted: 21.06 .2020 | Published: 18.07 .2020

*Corresponding author: Wambui Phyllis Wagacha

\section{Abstract}

Research in Kiambu County shows a variety of farmers' information needs. Among subsistence farmers who produce a mix of food and cash crops, land size is 2-2.9 acres. Large-scale farmers grow more cash crops. Most farmers keep dairy cattle for milk and manure. This paper focuses information needs on credit, the key emerging issues. Using a descriptive research design we gathered qualitative and quantitative data on how farmers accessed credit information they needed; sources; and usage. We took a random sample of 150 farmers, 18 to 55 years, selected from 897 farmers, covering 28 cooperatives. A descriptive research design was applied. Stratified Random Sampling technique was used, with face-toface interviews and semi-structured questionnaires. Face-to-face interviews and semi-structured questionnaires were used. Specifically, we itemized a) farmers' information needs and search on the sub-clusters-loans availability from providers, interest rates charged, availability of low interest rates, supplementary services offered by credit providers, and availability of government funds; b) information sources from the cluster: Cooperatives, Banks, Government Offices, Churches, NGOs, No information access, Salesmen, and Other people; and c) usage of the information and challenges thereof. The study reveals access to information on loan availability by providers, interest rates charged, and lowest interest rates were the most sought-after sets (in that order). Government funds information is the least sought. Top providers are Cooperatives, Banks and Government, in that order. On usage, loans from the cooperatives and banks finance projects such as construction of boreholes, increasing dairy animals or planting additional crops. Credit from cooperatives is flexible. It may feature loans in kind, e.g., animal feeds.

Keywords: Access to and use of information, farmers credit information needs, information sources, information providers; information usage.

Copyright @ 2020: This is an open-access article distributed under the terms of the Creative Commons Attribution license which permits unrestricted use, distribution, and reproduction in any medium for non-commercial use (NonCommercial, or CC-BY-NC) provided the original author and source are credited.

\section{INTRODUCTION}

Small-scale and big farmers in Kiambu County, in the central region of Kenya, require information on financing their farming activities. They need access to information on credit facilities so that they can access credit and advance their production and hence improve their livelihood. Agricultural land in the county per capita holdings has continued to diminish due to population pressure which prescribes the way the land is utilized. The result is small land holdings per household, and this leaves the farmer with no option but to increase production. Most of the farmers have less than 0.5 hectares and their marginal tendency to save is low Kuria [1]. Farmers therefore require information on credit facilities to finance and improve their production. This include financing of modern agricultural equipments and improved technologies. The County has a population of over 1.6 Million according to Economic Survey [2], and covers an area of 2,543.42.

Farmers in this County specifically need information, on availability of credit, information on sources of such information i. e. information providers, the existing and kind of credit programmes, the sources of credit, i. e. the suppliers of the financial products, and this information lead to acquisition of information on financial services, information on products that are being offered and the costs of these financial services, information on basic loan requirements Adebayo, O.O. and Adeola, R. G [3], and Abdullah, H. and Manan, T [4], on collateral, interest rates charged, information on those financial establishments offering low interest rates and available government funds. Farmers' additionally need information on channels used to access information. 
The providers of information on credit facilities are also mainly the same involved in agricultural financing, i.e. providers of credit facilities. These are the Cooperatives, Banks, Government agencies, Churches and NGOs and including SACCOs. However, their actual investment in the agricultural production could be much improved if the provision of information matched farmers' needs as observed by Mwangi, I and Sichei, M [5], access, and detail on availability of credit facilities. In order to raise the level of credit access of smallholder farmers, and therefore attract more of them, financial institutions need to educate the farmers and repackage their loan products to suit the farmers' needs, as noted by Kimuyu, P. and Omiti, J [6], and Atieno, R [7]. A suitable product is one that takes into consideration both the credit attributes and the farmers' 'needs' characteristics, as they all jointly affect the farmers' choice of credit source.

Rahji and Fakayode [8], supposed that lack of access to loans or credit was because of limitation on "imperfect and costly" information problems encountered. This lack of access to information on credit facilities could be among the reasons why smallscale farmers in Kenya only absorb about a third of total agricultural credit that is available to them despite the fact that they account for about $80 \%$ of the marketed agricultural produce in Kenya Odhiambo et al., [9].

Information on credit facilities in Kiambu County is inadequate. There are many reasons for this. First there are hardly any information on financial policies, especially for the small-scale farmers. These farmers encounter other problems that hinder them from accessing credit facilities. Their level of education is low and they will need assistance in acquiring and comprehending bank related materials. Education, as noted by Mwangi [10], is a vehicle that drives a person's ability to access information because it helps in understanding what is actually needed by financial institutions and developing skills fit for preparing and originating projects that can attract credit from financial institutions. Financing Institutions like banks, use written material to deliver information to farmers. This means that the information is aimed at the literate and therefore credit services are biased towards them, most of them being women. This was noted much earlier by Atieno, R., and Hayangah R [11], and later by Odini, S. M. C [12], who believes in empowerment of women by providing them with the information they require including information on credit facilities. .

Media facilities used by some financial institutions such as radios and televisions as well as social internet media platforms are only available to those with access to such facilities. Farmers might not know what information is required of them, even about the potential of their land so that they are not able to provide the banks, cooperatives, or any of their potential financiers, detailed information about themselves. Farmers need to be informed on the need to have proper financial records which is information required by banks and which, if not available, can hinder them from accessing credit.

Odini [13], states that information systems in the country are so much under- utilized owing to various factors such as poor infrastructure and this suggests that banks and other institutions could be holding information unknown to farmers, for example information on the requirements of getting and paying loans, information about lending terms and conditions on access to credit facilities. They are not aware that provision of their information to the financiers is a prerequisite for accessing credit. On the other hand, the lenders, banks, cooperatives etc. might not have enough information on farmers (the borrowers). Their earning and spending habits and might find it not worthwhile and even costly to take credit services close to the rural small-scale farmers.

Given that farmers need access information on credit facilities so that they can access credit and advance their production and hence improve their livelihood, availability and accessibility of information on credit lead to acquiring the actual finances needed to fund agricultural activities, information on basic loan requirements, on collateral and information on interest rate charged etc. Farmers need to be informed on the need to have proper financial records which is information required by banks and which if not available can prevent them from accessing credit. Access to credit is a major problem, especially in the rural areas where farming takes place. Economic Survey 2009, shows that 50 percent of the rural individuals had never used any credit service. For Kiambu County access to information on credit facilities signifies better agricultural yields, better incomes and uplifted livelihood especially for the rural smallholder agricultural farmers. For farmers with bigger land, financial credit would facilitate acquisition of new farming technology and therefore improved productivity that would enable Kiambu County to meet its demand for food items and even supply the same to the neighboring counties.

Information on access to credit is important to farmers in Kiambu County where nearly $60 \%$ of smallscale farmers have nearly $80 \%$ of their land on food crop production. This article considers that farming community requires information on credit facilities that can advance their production for agricultural development and improved livelihood. Access to information on credit facilities can make a difference in Kiambu county and its surroundings. 


\section{OBJECTIVES OF THE STUDY}

This article sought to establish farmers' information needs on availability of credit facilities in Kiambu County, their sources of information, how they made use of that information, and the challenges they experience while seeking information.

\section{LITERATURE REVIEW}

Adegeye et al., [14], defined agricultural credit as the process of acquitting control over the use of money, goods and services in the present in exchange for assurance to repay in a future date. Odini, C [15], believes that information providers and experts should listen to the information needs of various groups of information users like the farming community. Rural farmers have specific needs and these needs differ depending on underlying forces, like for example, need to access information on financial services. He observes in Odini, C [16], that identifying information needs is imperative in satisfying information needs and that information seeking was influenced by the activity and problem at hand. This means that if farmers were looking for information on credit facilities, they would go to the institution that they perceive has the information they need. Mchombu [17], believes that information seeking behavior of farmers is complex and necessities for the use of information seeking approaches and a well thought out communication system.

A study done on factors influencing smallholder dairy farmers' choice of agricultural credit by Wachekeh [18], in Githunguri, Kiambu County, reveals that most farmers have small pieces of land. Their needs are: Land, Labour and Capital, out of which Capital is the most important, since labor can be supplemented with a free familial labor, as opposed to hired labor, whereas land can only be improved through use of improved technologies which require Capital. Capital could be obtained either from savings or credit. Mostly farmers opt for credit since they are not able to save enough from their agricultural produce. Their marginal tendency to save is low, Kuria [1]. A case study on the capital on land and land tenure effects on agricultural sustainability in Limuru, Kiambu, by Mbugua [19], agrees the small sizes of farm land as capital on land is one solution to agricultural productivity and sustainability. Though most of the county is sub-divided into small pieces of land, farmers can still inject capital for greater output. Staal et al., [20], observed that the intensification of dairy production in Kiambu, where zero glazing is practiced, (because of the small sizes of farm land), can potentially raise milk production and income, especially where demand and infrastructure are favorable, and consequently has the potential to improve the incomes of smallholder farm households in an economically sustainable manner. Access to credit would augment production, and consequently agricultural development, Diagne, A. and Zeller, M [21], point out that for credit to work effectively and be useful to farmers, "conditions surrounding credit programs must be right" like access to roads, markets, healthcare and communication infrastructure and measures taken to curb drought that can destroy a harvest.

According to Akobundu [22], information seekers and users may not know about the resources available. Farmers need information on where to get credit to improve and increase their farm produce. Hence they need to know where to get it, the cost involved and repayment period, among other things. Spence, B. and Stiglitz, T [23].

Farmers are usually more credit constrained than other segments of the economy because of a low level of access to information on credit and complicated borrowing procedures. Low level of education among the farming community is a contributing factor as noted by Mwangi [24]. During the interview some farmers pointed out that if they had a better education, they would be better informed than they were. Besides, the proximity to information sources is an important factor. Physical distance of farm household from lending institutions is a problem that farmers encounter in accessing credit facilities. This is supported by Mwangi [24], who discloses that long physical distance to the nearest financial services provider, is one of the reasons for not sourcing from formal financial institutions. Besides most farmers, especially the small-scale farmers find information emanating from the banks, complicated. The information is sometimes presented in a format that is not user friendly. In her study on factors influencing smallholder dairy farmers' choice of agricultural credit in Githunguri, Kiambu County, Wachekeh, felt that banking information should be repackaged to be understood by the farmers and enable them to take advantage of credit facilities [18].

Financial service providers on the other hand require information from farmers, with which to assess the risk before they commit their funds. Though the small-scale farmers possess more information about the potential of their financial needs, it can be difficult for them to articulate and give detailed information required by financing institutions, and this prevents them from accessing loans. In their study on credit facilities in Githunguri Kenya, Nyaga and Nzulwa [25], established that farmers lack of information and collateral were significant factors that hindered smallscale farmer's access to credit facilities and that farmers should be enlightened on the credit process. This is supported by Kinyanjui [26], who backed credit records as important in accessing loans. He felt that even entrepreneurs found it difficult to obtain loans as they had to show credit records, and like farmers, some did not fully understand the requirements of getting and paying loans. The situation is more difficult for farmers with low level of education or the illiterate, most of whom are members of farmers' cooperatives. 
The cooperatives are farmers' most attractive choice of credit sources as they provide simpler and less formal information on credit facilities. They provide information on the processing of loans, time taken to process, loan repayments schedules to suit farmers' income availability, etc. Besides providing information, the cooperatives appeal especially to the small-scale farmers by providing them not only with finances but process their loans within a short time, and could reorganize their loan repayments to suit their earnings or income availability. The cooperatives also offer them loans in kind like animal feeds, food stuffs and loans for purposes other than for agricultural purposes, such as school fees. The cooperatives are less formal, and that their products were geared towards the interest of their members.

\section{RESEARCH METHODOLOGY}

The study applied descriptive research design with the aim to gather qualitative and quantitative data to find out how farmers accessed the information they needed, from what sources, on access to credit and how they used the information. The target population composed of farmers selected from among smallholders and big cash crop growers living in the rural area of Kiambu County. The study sampled 150 farmers ranging from 18 to 55 years, randomly selected from a population of 897 farmers from the largest and the smallest segments in a register of 28 cooperatives. Stratified random sampling technique was then used to achieve representativeness. Data was collected from the farmers using face to face interview and semi-structured questionnaires.
The study used interpretive and descriptive techniques, respectively. Creswell J. W [27], and Onwuegbuzie, A. J., and Leech, N. L [28], acknowledges the strength of use of the two approaches together. Since the study was mainly qualitative, the interpretive method was used to answer questions with the aim of understanding farmers' information needs from their own perspective, their information seeking behavior their sources of information and how they get and use it. It allowed the researcher to view the world through the perceptions and experiences of the farmers in Kiambu county. The researcher used quantitative descriptive technique to supplement qualitative technique mainly to explain the phenomenon through data analysis, to summarize the findings in terms of frequencies, percentages and intensities. The methodology was informed by Niedzwiedzka, B [29], theoretical framework, "New Model of Information Behavior." The model was chosen because it incorporates aspects of information needs, information seeking and information use, that were the subject of the investigation.

\section{Data presentation, analysis and interpretation}

The study found that information on an educational level of the farmers, land ownership and size, and farming activities were important factors in advancing the need, access to and use of information on credit facilities.

\section{Educational level versus gender}

The analysis of the level of education of men versus women is presented in Table-1.

Table-1: Education vs gender in the sampled population

\begin{tabular}{|l|l|l|l|l|}
\hline Education Level & Frequency & percentage & Frequency & percentage \\
\hline & Male & & Female & \\
\hline Secondary complete & 44 & 29.3 & 24 & 16 \\
\hline Secondary, incomplete & 12 & 8 & 5 & 3.3 \\
\hline Primary complete & 5 & 3.3 & 3 & 2 \\
\hline Primary incomplete & 8 & 5.3 & 7 & 4.6 \\
\hline None & 3 & 2 & 5 & 3.3 \\
\hline Certificate & 15 & 10 & 9 & 6 \\
\hline Diploma & 4 & 2.6 & 0 & 0 \\
\hline University & 6 & 4 & 0 & 0 \\
\hline Total & 97 & 64.5 & 53 & 35.2 \\
\hline
\end{tabular}

The difference between men and women, (of those in the sample that had completed secondary school education) is men $44(29.3 \%)$ and women 24 (16\%). Those who had not completed secondary school were men $12(8 \%)$, and women $5(3.3 \%)$; those who had completed primary school were men $5(3.3 \%)$, women $3(2 \%)$. The difference of those who had not completed primary school is minimal between men 8 $(5.3 \%)$ and women $7(4.6 \%)$. Those with no education are women $5(3.3 \%)$ and men $3(2 \%)$. No woman had attained diploma or university education among those interviewed.

During the interview some farmers pointed out that if they had a better education, they would be better informed than they were. Some women felt that they would seek for information themselves instead of relying on their husbands or their male counterpart if they had better education. 


\section{Land Ownership, Size and Farming}

Most farmers owned less than three acres of land as shown by the Figure-1 below.

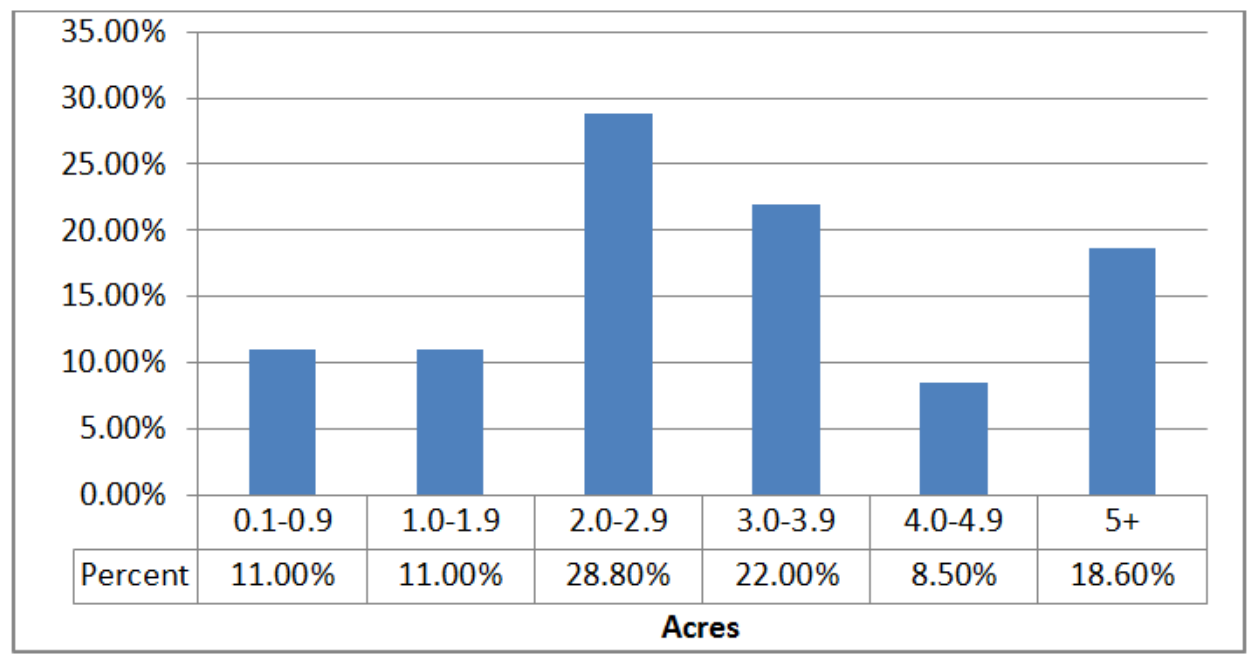

Fig-1: Land Ownership Size and Farming

The farmers used the land wholly and intensively mainly for mixed farming of non-cash crops like maize and legumes, while other farmers grew cash crops like tea, coffee and pyrethrum on a small scale. 16 $(10.6 \%)$ of the farmers owned between 0.1-0.9 acres, and $16(10.6 \%)$ owned between $1.0 \quad-1.9$ acres. However, land ownership in the county is unequal and uneven. The highest number of farmers 43 (28.6\%) owned between 2.0 and 2.9 acres, while the smallest number of farmers $14(9.3 \%)$ owned between 4.0 and 4.9 acres. The $28(18.6 \%)$ farmers who owned 5 plus acres were mostly cash crop farmers as shown also in Figure-1.

Owing to the small size of farms, farmers were generally reserved on seeking information on many aspects related to farming but were interested in information on credit facilities to improve their food production and hence their livelihood. The findings also suggest that since the small land brought in less income, farmers were compelled to seek for other incomegenerating activities outside their farms to supplement their incomes.

\section{Main farming activities in the county}

The study found that the main farming activities of the area surveyed are in dairy farming, followed by coffee and tea, respectively. Table- 2 shows the main farming activities reported by the respondents and the percentage each segment represented in the sample.

Table-2: Main farming activities

\begin{tabular}{|l|l|l|}
\hline Main farming activities & Frequency & Percent response rate \\
\hline Dairy & 80 & 53.3 \\
\hline Coffee & 43 & 28.6 \\
\hline Tea & 25 & 16.6 \\
\hline Pyrethrum & 1 & 0.7 \\
\hline Others & 1 & 0.7 \\
\hline Total & 150 & 100 \\
\hline
\end{tabular}

Over $50 \%$ farmers are engaged in dairy farming followed distantly by coffee farming $43(28.6 \%)$ and Tea $25(16.6 \%)$ pyrethrum 1(0.7\%) other 1 (0.7). Other than the three main farming categories, 'Other farming' was dominated by 'Food crop' farming, horticulture, chicken rearing and livestock. It is clear that the sampled area is intensive in dairy farming. Most farmers kept at least a cow for milk for livelihood.

Specific information needs on access to credit

Farmers specific needs are availability of loans, interest rates charged, services offered by financing institutions and availability of government funds. 


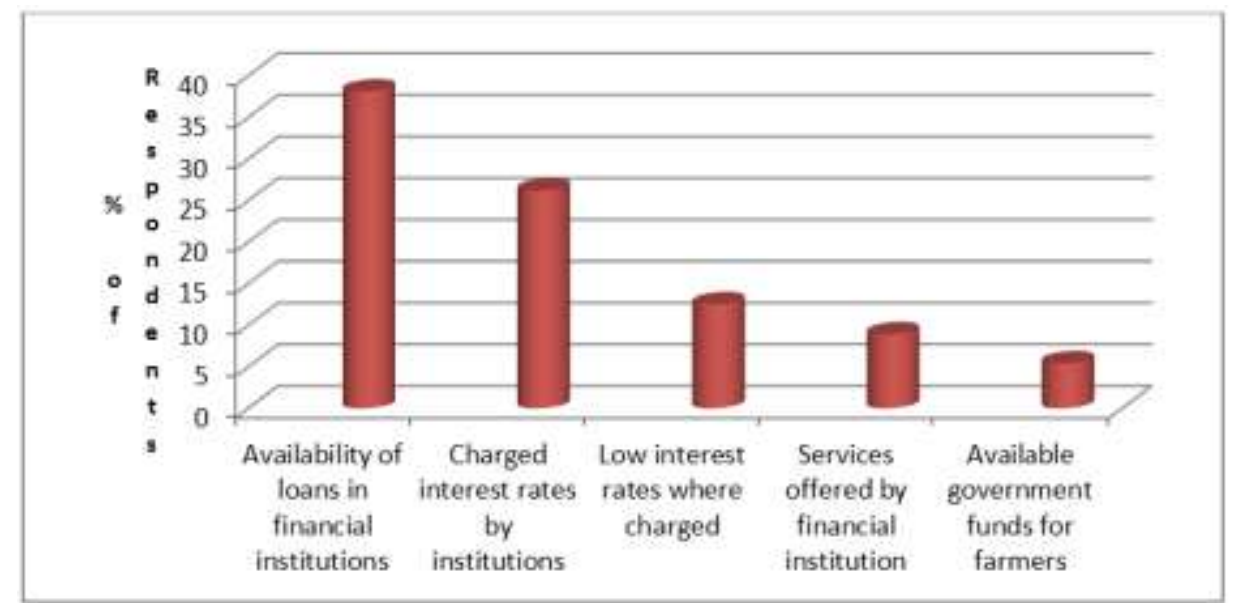

Fig-2: Information required on access to credit

Access to information on credit, the researcher identified 11 indicators signifying information needs. However, the most cited were the availability of loans $64(38.1 \%)$; information on actual interest rates charged by financial institutions 44 (26.2\%); and information on institutions that offered the lowest interest rates 15 $(8.9 \%)$; information on other credit related services offered by financial institutions 9 (5.4\%); and information on availability of government funds for farmers $5(3.0 \%)$; which included not only loans in money form but loans in kind like fertilizers and seeds. The farmers were interested in information on the existing and kinds of credit programs that can be of benefit to them, especially from financial institutions that were close to them. They indicated that they would be interested in information on varieties of loans available. Some farmers said they actually knew where to get loans but were not happy with the requirements set by some institutions. For example, some institutions only consider giving loans to trained and experienced farmers, others wanted to give only to registered groups and not to individuals because they believed that registered groups were more organized and it was easy to monitor their loan repayment.

The information needs on credit were directed at financial market services and conditions thereof. There is need for information on the availability of loans as indicated by the high percentage of information need in this category but the need to get information on interest rate and even on lowest interest rate charged, is a pointer that farmers are to some extent knowledgeable of their financial information needs. They also wanted to have information on services offered by financial institutions which meant that they were aware that financial institutions had other complimentary services farmers might benefit from. The lowest information need is on funds from the government.

\section{Access to credit information sources}

The study sought to discover sources of information on credit facilities, presented in Table-3.

Table-3: Sources of information on access to credit

\begin{tabular}{|l|l|l|}
\hline Source & Count & Percentage response rate \\
\hline Cooperative & 80 & 53.3 \\
\hline Banks & 20 & 13.3 \\
\hline Government offices & 18 & 12.0 \\
\hline Churches & 10 & 6.6 \\
\hline NGO's & 10 & 6.6 \\
\hline No information access & 7 & 4.6 \\
\hline Salesmen & 3 & 2.0 \\
\hline Other people & 2 & 1.3 \\
\hline Total & 150 & 100 \\
\hline
\end{tabular}

The study disclosed that the leading sources of information on credit were various cooperatives 80 $(53.3 \%)$, followed by the banks $20(13.3 \%)$, the government $18(12.0 \%)$, then churches $10(6.6 \%)$ and NGO $10(6.6 \%)$ each, respectively. Churches and NGOs, who were good at passing on information on access to credit from other institutions, from banks and international organizations.

The study has shown therefore that various cooperatives and specifically not the banks were by far the main sources of information on credit facilities. The farmers felt that being a member of a cooperative was 
more beneficial because the cooperative brought the information closer to the farmers, whereas the banks want the farmers to go to them.

In summary, cooperatives were the main providers of information on credit facilities. The farmers felt that the NGOs and Churches were good at passing on information on access to credit from other institutions like banks and international organizations. The NGO's and Churches were mainly concerned with information on the use of finances rather than the credit facilities. They were of the opinion that though access to information from capacity building groups, Salesmen, printed and audio media was limited, the information they gave was specific to them, on how to access credit, on how to use it; and also inform farmers of the consequences if the farmers defaulted.

\section{Use of available information on credit facilities}

The study found out that a number of farmers especially those with bigger pieces of land had made use of the available information to get loans and were actually using the money from the cooperatives and banks to finance some of their projects like construction of boreholes and increasing their dairy animals or planting additional crops. Credit information is more intensively acquired from cooperatives than from banks. However, in some cases the loans they received from the cooperatives were in kind. For example, dairy farmers can get animal feeds and pesticides and pay at the end of the month from their milk, which they deliver daily to the cooperative. The cash crop farmers, especially' those growing tea, coffee and pyrethrum used the money to buy equipment, transport facilities to help them get produce to the markets. However, for the small farmers, the loans they got were very limited since they could not service big loans. They were interested in getting more information, especially on financial institutions that support them to access bigger loans which they can service for longer periods, from what the banks and cooperatives offer. Also other services offered by the same financial institutions like training and skills development on financial management.

\section{Challenges of access to information on access to credit}

The main challenge was unavailability of enough information on credit facilities owing to lack of suitable information services and physical distance of information providers. Most banks are located in urban areas with few branches located in rural centres, most of them without all the information the farmers require, making it difficult to provide adequate information and services to farmers. Inadequate communication and information infrastructure and low literacy level. Also the way the information was repackaged, especially by the banks, the formal financial institutions.
Farmers found that some bank based information was complicated and sometimes presented in a format that was not user-friendly. They also felt that the main banks provided information that was directed at benefiting the banks other than the farmers. Information, for example on interest rate charged by these banks was not presented in simple form that farmers would understand. Some farmers were therefore hesitant in applying for loans especially the small-scale farmers who felt that they might not be able to service their loans. In their study Nyairo and Njuguna [30], found that financial institutions credit rationing using interest rates was less friendly and had locked out most individuals including small farmers so that farmers were forced to sick assistance from non -formal financial agents. Farmers however need credit for improved crop production for themselves and enough surplus for sale for improved income and better livelihood.

\section{CONCLUSION}

That though farmers in Kiambu county were interested in getting credit to advance their agricultural production, information on credit facilities was not easily available.

That information needed to be brought close to the farmers. Proximity to information sources was found as key to accessing information.

That there is a need to raise the level of literacy of farmers. The study found that farmers with a high literacy level understood more of what was required of them by especially formal financial institutions like banks.

That in order to raise the level of credit access of smallholder farmers, and therefore attract more farmers, financial institutions need to educate the farmers and repackage their loan products to suit the needs of the farmers.

\section{RECOMMENDATIONS}

That information need to be brought close to the farmers. Proximity to information sources was found as a key to accessing information. Women more than men were involved in agricultural activities, but they could not leave their homes, (their center of activity) to look for information. Hence information should be brought close to the people and specially to women farmers.

Communication infrastructure including electricity should be improved to facilitate efficient and economical use of information technology including use of mobile phones, radio and television, information channels the farmers were using as revealed by the study. 
The study revealed that the farmers who owned bigger pieces of lands were more interested in searching for information than those who did not have or had small pieces of land. Therefore, information on right to own land by men and woman should be properly communicated by both National and County governments. In addition to providing the farmers with information about land and farming activities, they should be facilitated to acquire ownership of their land so that they can use it effectively, especially as collateral for credit access.

The government should have policies on access to information that guide the small-scale farmers, on land use and agricultural production and most important on credit facilitation so that farmers can access technology and use their land effectively.

\section{REFERENCES}

1. Kuria, C. W. (2014). Use of social media as a source of agricultural information by small holder farmers; a case study of lower Kabete, Kiambu county (Doctoral dissertation, University of Nairobi).

2. GoK. (2009). Economic Survey. Kenya Bureau of Statistics report of 2009.

3. Adebayo, O. O., \& Adeola, R. G. (2008). Sources and uses of agricultural credit by small-scale farmers in Surulere Local Government Area of Oyoo State. In: Anthropologist, 10(4):313-314.

4. Abdullah, H., \& Manan, T. (2011). Determinants of bank credit access for small holder farmers in Tanzania: a discriminant analysis application. Saving and Development, 3: 285-97.

5. Mwangi, I., \& Sichei, M. (2009). Determinants of access to credit by individuals in Kenya. a comparative analysis of the National FinAccess surveys of 2006 and 2009. European Journal of Business and management. 3:207.

6. Kimuyu, P., \& Omiti, J. (2008). Institutional impediments to access to credit by micro and small scale enterprises in Kenya. Institute of Policy Analysis and Research.

7. Atieno, R. (2001). "Formal and informal institutions" lending policies and access to credit by small-scale enterprises in Kenya: an empirical assessment. African Economic Research Consortium, Nairobi.

8. Rahji, M. A. Y., \& Fakayode, S. B. (2009). A multinomial logit analysis of agricultural credit Rationing by commercial Banks in Nigeria. International Research Journal of Finance and Economics, 24.

9. Odhiambo, W., Nyangito, H., \& Nzuma, J. (2004). Sources and determinants of agricultural growth and productivity in Kenya, Nairobi. KIPPRA Discussion Paper no. 34.

10. Mwangi. (2009). Impact of financial literacy on access to credit by households in informal settlements in Nairobi. Unpublished MBA Thesis, University of Nairobi.

11. Atieno, R., \& Hayangah R. (1992). Women's role in agricultural food production in Kenya. The case of Siaya District: Eastern Africa Social Science Research Review. 8(2).

12. Odini, S. M. C. (2009). Empowering rural women in Kenya to alleviate poverty through provision of information: the case of Vihiga District in Western Kenya. PhD Thesis. Eldoret: Moi University.

13. Oni, C. (2005). Information seeking and communication behavior of Kenya Railways Engineers. University of Dar es Salaam Journal. $7(2)$.

14. Adegeye, A. J., \& Ditto, J. S. (1985). Essentials of Agricultural Economics. Impact Publishers Nigeria Limited, Ibadan. 5.

15. Odini, C. (1995). Stimulating the use of information in Kenya. Library World, 96(119), 2325.

16. Odini, C. (2005). Information seeking and communication behavior of Kenya Railways Engineers. University of Dar es Salaam Journal. 7(2).

17. Mchombu, K. J. (2006). Libraries, literacy and poverty reduction: a key to African Development. A research paper looking at libraries in Africa Commissioned by Book Aid International and sponsored by the Commonwealth Foundation.

18. Wachekeh, S. W. (2013). An identification and evaluation of factors influencing smallholder dairy farmers' choice of agricultural credit source: The case of Githunguri Division of Kiambu County (Doctoral dissertation, University of Nairobi).

19. Mbugua, E. K. (2012). Capital on land and land tenure effects on agricultural sustainability case study of Limuru area. A research project paper submitted as part fulfilment of the requirements for an award of a degree in B.A. Land Economics, Department Real Estate and Construction Management, Faculty of Architecture, Design and Development, University of Nairobi.

20. Staal, L., Chege, M., Kinyanjui, A., Kimari, B., Lukuyu, D., Njubi, M., Owango J., Tanner, W., \& Wambugu, M. (1997). Characterization of dairy systems supplying the Nairobi milk market: A pilot survey in Kiambu District for the identification of target groups of producers. KARI/MoA/ILRI Collaborative Research Project Report. Nairobi: ILRI.

21. Diagne, A., \& Zeller, M. (2001). Access to credit and its impact on welfare in Malawi. International Food Policy Research Institute, Research Report; 116.

22. Akobundu, D. U. (2007). Obstacles to information access and use in developing countries. Library Philosophy and Practice, 2007. https://digitalcommons.unl.edu/libphilprac/160 
23. Spence, B., \& Stiglitz, T. (2001). Determinants of bank credit access for small holder farmers in Tanzania: a discriminant analysis application. Saving and Development, 3: 285-97.

24. Mwangi, R. (2011). An evaluation of the role of Agency Banking in the performance of commercial Banks in Kenya. MBA Thesis, Kenyatta University, 45-48.

25. Nyaga, J. O. Y. C. E., \& Nzulwa, D. J. (2017). Strategic factors affecting access to credit facilities by smallholder dairy farmers in Githunguri subcounty, Kiambu county, Kenya. Strategic Journal of Business \& Change Management, 4(2).

26. Kinyanjui, M. N. (2006). Overcoming barriers to enterprise growth: the experience of MSEs in rural central Kenya. Nairobi, Kenya.

27. Creswell, J. W. (2009). Research design. Qualitative, quantitative and mixed methods approaches. Los Angeles: Sage.
28. Onwuegbuzie, A. J., \& Leech, N. L. (2005). On becoming a pragmatic researcher: The importance of combining quantitative and qualitative research methodologies. International journal of social research methodology, 8(5), 375-387.

29. Niedzwiedzka, B. (2003). A proposed general model of information behaiour. Information Research. 9(1):164. Retrieved August 30, 2011, from ../ir/9-1/paper164. Html (ArchivedbywebWebcite ${ }^{8}$ ). Hltp://www.webcitation.org/6CH7RXJin).

30. Nyairo, N. M., \& Njuguna, E. (2015). Formal conditions that affect agricultural credit supply to small-scale farmers in rural Kenya: case study for Kiambu County. International Journal of Science: Basic and Applied Research. 20(2):59-66. 